\title{
Fabrication of carbonate apatite pseudomorph from highly soluble acidic calcium phosphate salts through carbonation
}

\author{
Yuki SUGIURA, ${ }^{\dagger}$ Kanji TSURU and Kunio ISHIKAWA \\ Department of Biomaterials, Faculty of Dental Science, Kyushu University, \\ 3-1-1 Maidashi, Higashi-ku, Fukuoka 812-0044, Japan
}

\begin{abstract}
B-type carbonate apatite $\left(\mathrm{CO}_{3} \mathrm{Ap}\right)$ has recently emerged as an attractive bone scaffold material because it exhibits significantly higher osteoconductivity than its hydroxyapatite analogue. Highly soluble acidic calcium phosphate salts, such as calcium hydrogen phosphate dehydrate (DCPD) and monocalcium phosphate monophosphate (MCPM), are typically used as bone cement and easily produce large calcium phosphate crystals. However, few studies have focused on these salts as precursors despite extensive investigations on the production of $\mathrm{CO}_{3} \mathrm{Ap}$. In this study, DCPD and MCPM were converted into $\mathrm{CO}_{3} \mathrm{Ap}$ by hydrothermal treatment in the presence of at least $0.5 \mathrm{~mol} / \mathrm{L} \mathrm{NaHCO}_{3}$, which acted as a neutralizer and $\mathrm{CO}_{3}{ }^{2-}$ releaser. $\mathrm{The}^{2}$ obtained material maintained precursor morphologies and was therefore regarded as a pseudomorph of DCPD and MCPM mesocrystal structures. This synthetic approach is expected to facilitate the fabrication of shape-controlled $\mathrm{CO}_{3} \mathrm{Ap}$ compacts from DCPD and MCPM.
\end{abstract}

(C2016 The Ceramic Society of Japan. All rights reserved.

Key-words : Carbonate apatite $\left(\mathrm{CO}_{3} \mathrm{Ap}\right)$, Acidic calcium phosphate, Phase conversion, Pseudomorph, Bone scaffold

[Received February 25, 2016; Accepted May 22, 2016]

\section{Introduction}

B-type carbonate apatite $\left[\mathrm{CO}_{3} \mathrm{Ap}: \mathrm{Ca}_{10-\mathrm{a}}\left(\mathrm{PO}_{4}\right)_{6-\mathrm{b}}\left(\mathrm{CO}_{3}\right)_{\mathrm{c}}(\mathrm{OH})_{2-\mathrm{d}}\right]$ is a calcium phosphate mineral in which carbonate ions $\left(\mathrm{CO}_{3}{ }^{2-}\right)$ partially replace the phosphate ions $\left(\mathrm{PO}_{4}{ }^{3-}\right)$ of hydroxyapatite [HAp: $\mathrm{Ca}_{10}\left(\mathrm{PO}_{4}\right)_{6}(\mathrm{OH})_{2}$ ]. This main bone component is transformed into new bone through bone remodeling, ${ }^{1)-6)}$ making its scaffolds highly attractive candidates as bone substitutes in bone reconstruction applications. ${ }^{1)}$

Unlike other ceramics, $\mathrm{CO}_{3} \mathrm{Ap}$ compacts cannot be obtained by conventional sintering processes because it decomposes at sintering temperature. ${ }^{7)-9)}$ Instead, it is fabricated by phase conversion using calcium salt precursors, such as $\mathrm{CaCO}_{3}, \mathrm{Ca}(\mathrm{OH})_{2}$, alpha-tricalcium phosphate, and gypsum. ${ }^{10)-18)}$ This synthesis relies on a hydrothermal or solution-mediated dissolutionprecipitation process, in which the salt precursor phase initially dissolves and releases $\mathrm{Ca}^{2+}$ ions into the surrounding solution. The $\mathrm{Ca}^{2+}$ concentration in the surrounding solution increases as the precursor phase continues to dissolve. When the precursor gradually releases $\mathrm{PO}_{4}{ }^{3-}$ and $\mathrm{CO}_{3}{ }^{2-}$ in addition to $\mathrm{Ca}^{2+}$, the concentrations of these ions begin to exceed the solubility of $\mathrm{CO}_{3} \mathrm{Ap}$. This causes $\mathrm{CO}_{3} \mathrm{Ap}$ to precipitate from the saturated solution:

$$
\begin{aligned}
& (10-\mathrm{a}) \mathrm{Ca}^{2+}+(6-\mathrm{b}) \mathrm{PO}_{4}{ }^{3-}+\mathrm{cCO}_{3}{ }^{2-}+(2-\mathrm{d}) \mathrm{OH}^{-} \\
& \quad \rightarrow \mathrm{Ca}_{10-\mathrm{a}}\left(\mathrm{PO}_{4}\right)_{6-\mathrm{b}}\left(\mathrm{CO}_{3}\right)_{\mathrm{c}}(\mathrm{OH})_{2-\mathrm{d}}
\end{aligned}
$$

The rate of this reaction depends on the precursor solubility. Calcium hydrogen phosphate dihydrate [DCPD: $\mathrm{CaHPO}_{4} \cdot 2 \mathrm{H}_{2} \mathrm{O}$ ] and monocalcium phosphate monohydrate [MCPM: $\mathrm{Ca}\left(\mathrm{H}_{2} \mathrm{PO}_{4}\right)_{2}$. $\mathrm{H}_{2} \mathrm{O}$ ] present high solubility in calcium precursor salts. ${ }^{2), 3)}$ In addition, these calcium phosphate minerals readily give rise to large crystals that can be interlocked. ${ }^{3)}$ These physicochemical properties, which are suitable for the development of binding

$\uparrow$ Corresponding author: Y. Sugiura; E-mail: ysugiura@dent. kyushu-u.ac.jp materials, have led to the application of these minerals as main components of brushite cement. Moreover, DCPD and MCPM bind other $\mathrm{CO}_{3} \mathrm{Ap}$ precursors, such as calcites, to set. ${ }^{19)}$ These properties are especially appealing for the quick and shapecontrolled fabrication of $\mathrm{CO}_{3} \mathrm{Ap}$ compacts. ${ }^{4)}$

To achieve such a fabrication, a method that directly converted DCPD and MCPM into $\mathrm{CO}_{3} \mathrm{Ap}$ was developed in this study. Upon dissolution, these precursors release $\mathrm{H}^{+}$along with $\mathrm{Ca}^{2+}$ and $\mathrm{PO}_{4}{ }^{3-}$ because of their intrinsic acidity. However, $\mathrm{OH}^{-}$plays an essential role in the formation of $\mathrm{CO}_{3} \mathrm{Ap}$, which limits reaction media to basic solutions. Therefore, the synthesis was conducted in the presence of $\mathrm{NaHCO}_{3}$, which simultaneously produced $\mathrm{CO}_{3}{ }^{2-}$ and neutralized the released $\mathrm{H}^{+}$.

\section{Experimental methods}

\subsection{Fabrication of $\mathrm{CO}_{3} \mathrm{Ap}$ from precursor}

DCPD and $\mathrm{NaHCO}_{3}$ were purchased from Wako Pure Inc., Japan. MCPM was acquired from Sigma-Aldrich Co., USA.

DCPD $(1.72 \mathrm{~g}, 10 \mathrm{mmol})$ or MCPM $(2.52 \mathrm{~g}, 10 \mathrm{mmol})$ was immersed in $\mathrm{H}_{2} \mathrm{O}(0.015 \mathrm{~L})$ in the presence of $\mathrm{NaHCO}_{3}(0-6.3 \mathrm{~g}$, $0-5 \mathrm{~mol} / \mathrm{L}$ ) and hydrothermally treated at $200^{\circ} \mathrm{C}$ for $24 \mathrm{~h}$. The specimen was consecutively washed with distilled water at least ten times and $99.5 \%$ ethanol before slow drying at room temperature.

The specimens for crystalline and chemical analysis were milled using agate mortar and pestle. The milled specimens were additionally washed using distilled water to completely remove residual $\mathrm{NaHCO}_{3}$.

\subsection{Material characterization method}

Sample surfaces were examined by scanning electron microscopy (SEM) at an acceleration voltage of $5 \mathrm{kV}$ using an S-3400N instrument (Hitachi Co., Japan). Fine structures of treated materials deposited on copper microgrids covered with hollow carbon films were observed by transmission electron microscopy (TEM) 
using a JEM-1400Plus apparatus (JEOL Co., Japan) operating at an acceleration voltage of $100 \mathrm{kV}$.

The $\mathrm{pH}$ of the reaction medium after hydrothermal treatment of DCPD and MCPM in the presence of various $\mathrm{NaHCO}_{3}$ concentrations was measured using a $\mathrm{pH}$ electrode (LAQUA 952510D, Horiba Co., Japan) connected to a $\mathrm{pH}$ meter (LAQUAact D-71, Horiba Co., Japan) at room temperature.

Crystal phases were determined by X-ray diffraction (XRD) using a D08 ADVANCE instrument $(\mathrm{Cu} \mathrm{K} \alpha$ radiation, Bruker Co., Germany) operating at a voltage of $40 \mathrm{kV}$ and current of $40 \mathrm{~mA}$ in a continuous scanning mode for $2 \theta$ values ranging between 3 and $70^{\circ}$. These $2 \theta$ values were calibrated using the auto calibration mode before measurements. The scanning rate amounted to $150^{\circ} / \mathrm{s}$. Lattice parameters for $a$ - and $c$-axes were calculated using the (002) and (300) peaks of apatite observed at $2 \theta$ values of 21.78 and $32.94^{\circ}$, respectively, and the lattice parameter of the hexagonal system. Specifically,

$$
\frac{1}{d_{h k l}^{2}}=\frac{4}{3}\left(\frac{h^{2}+h k+k^{2}}{a^{2}}\right)+\frac{l^{2}}{c^{2}}
$$

where $h, k$, and $l$ are the Miller indices denoted as $(h k l), d_{h k l}$ is the $d$-spacing of $(h k l), a$ is the $a$-axis length of the unit lattice, and $c$ is the $c$-axis length of the unit lattice. For peak shift measurement, the peak position was calibrated by $\alpha$-alumina powder which mixed in specimens. The (012), (104) and (113) peaks of $\alpha$ alumina (Katayama Chemical Industries Co., Ltd., Japan) observed at $25.59,35.17$ and $43.38^{\circ}$, respectively, were used for calibration.

Chemical changes were evaluated by Fourier transfer infrared spectroscopy (FT-IR) in attenuated total reflection mode using a FT/IR-6200 apparatus (Jasco Co., Japan). Measurements were conducted over 32 scans at a resolution of $2 \mathrm{~cm}^{-1}$ using ambient air as the background. The carbon content (C) was determined by carbon-hydrogen-nitrogen (CHN) analysis using a MT-6 instrument (Yanaco Co., Japan) and Ar as a carrier gas. Samples were dried in a $\mathrm{P}_{2} \mathrm{O}_{5}$ desiccator before analysis.

\section{Results}

Figures 1(a) and 1(b) show SEM micrographs of typical DCPD crystals. These crystals presented elongated, hexagonal plate-like shapes averaging $200 \mu \mathrm{m}$ in length. They exhibited smooth surfaces devoid of hillock-like structures. Figures 1(c)1(h) show DCPD treated with $0.1(\mathrm{c}, \mathrm{d}), 0.5(\mathrm{e}, \mathrm{f})$, and $5 \mathrm{~mol} / \mathrm{L}$ $\mathrm{NaHCO}_{3}(\mathrm{~g}, \mathrm{~h})$. All treated samples retained the morphology of the initial phases, albeit with textured surfaces, except for DCPD treated with $0.1 \mathrm{~mol} / \mathrm{L} \mathrm{NaHCO}_{3}$. Samples exposed to $0.1 \mathrm{~mol} / \mathrm{L}$ $\mathrm{NaHCO}_{3}$ mainly consisted of a complex compact of ribbon-like crystals approximating $10 \mu \mathrm{m}$ in length and $2 \mu \mathrm{m}$ in width [Figs. 1(c) and 1(d)]. In addition, a small amount of block-like crystals measuring $20 \mu \mathrm{m}$ in length and $5 \mu \mathrm{m}$ in width was detected. Moreover, residual $\mathrm{NaHCO}_{3}$ was observed on samples treated at a concentration of $5 \mathrm{M}$ [Figs. $1(\mathrm{~g})$ and $1(\mathrm{~h})]$.

Figures 2(a) and 2(b) show SEM micrographs of typical MCPM crystals. These crystals exhibited slightly elongated diamond plate-like shapes averaging $700 \mu \mathrm{m}$ in length. Their surfaces were smooth and free of hillock structures. Figures 2(c)2(h) show SEM micrographs of MCPM treated with 0.1 (c, d), 1 (e, f), and $5 \mathrm{~mol} / \mathrm{L} \mathrm{NaHCO}_{3}(\mathrm{~g}, \mathrm{~h})$. The residual $\mathrm{NaHCO}_{3}$ was also observed on samples treated at a concentration of $5 \mathrm{~mol} / \mathrm{L}$ [Figs. 2(g) and 2(h)]. MCPM treated with 0.1 and $0.5 \mathrm{~mol} / \mathrm{L}$ $\mathrm{NaHCO}_{3}$ mainly consisted of $2 \mu \mathrm{m}$ in width in addition to a few block-like crystals measuring $20 \mu \mathrm{m}$ in length and $5 \mu \mathrm{m}$ in width. In contrast, samples treated $\mathrm{NaHCO}_{3}$ solutions exceeding

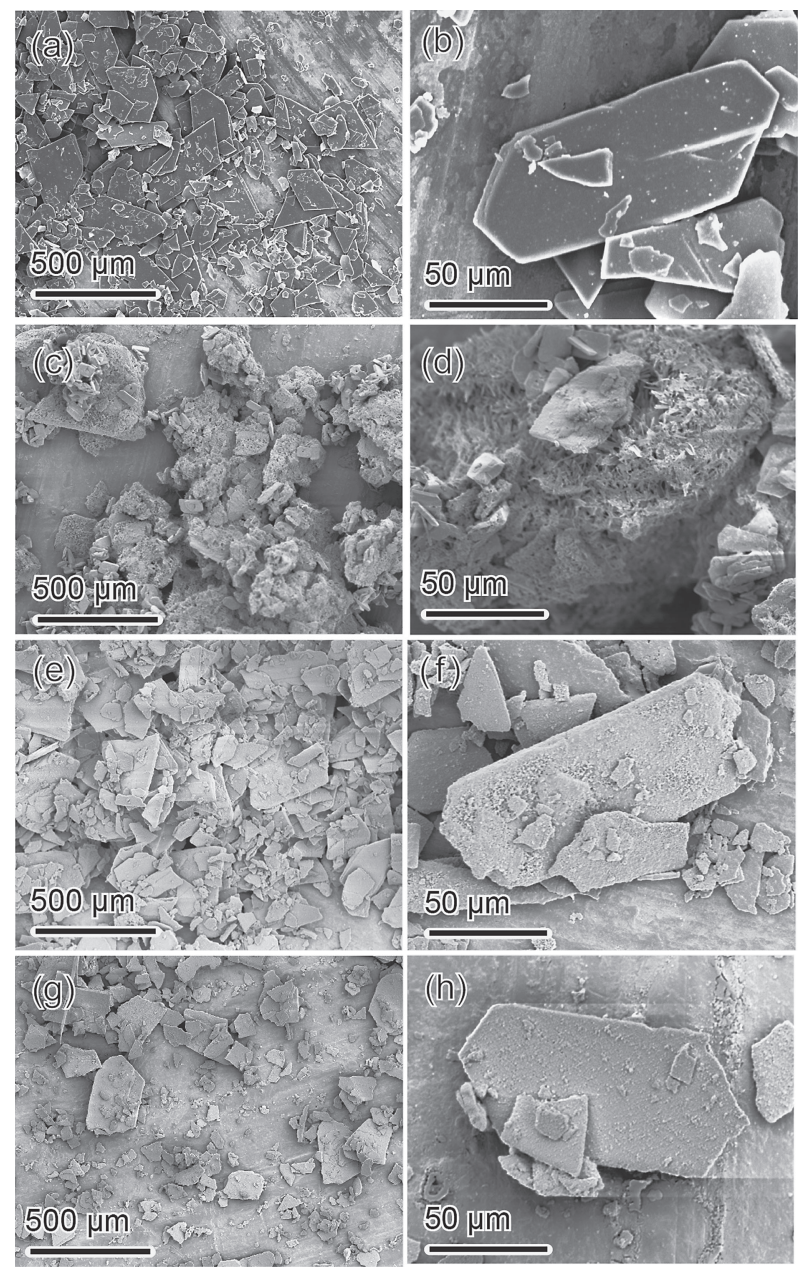

Fig. 1. SEM micrographs of $\operatorname{DCPD}(a, b)$ before and (c, d) after hydrothermal treatment with $0.1,(e, f) 0.5$, and $(g, h) 5 \mathrm{~mol} / \mathrm{L} \mathrm{NaHCO}_{3}$.

$1 \mathrm{~mol} / \mathrm{L}$ maintained the morphology of initial phases overall. Moreover, they presented textured surfaces similar to the treated DCPD equivalents.

Figures 3(a) and 3(b) show XRD patterns of treated DCPD and MCPM crystals, respectively. These patterns revealed that DCPD treated with $0.1 \mathrm{~mol} / \mathrm{L} \mathrm{NaHCO}_{3}$ dicalcium comprised hydrogen phosphate anhydrate (DCPA) as the main phase and a small amount of HAp $\left(\mathrm{CO}_{3} \mathrm{Ap}\right)$. A similar composition was observed for MCPM treated with $\mathrm{NaHCO}_{3}$ concentrations at or below $0.5 \mathrm{~mol} / \mathrm{L}$. In contrast, hydrothermal treatment with $\mathrm{NaHCO}_{3}$ solutions at or above $0.5 \mathrm{~mol} / \mathrm{L}$ and $1 \mathrm{M}$ yielded samples exhibiting typical HAp $\left(\mathrm{CO}_{3} \mathrm{Ap}\right)$ patterns for DCPD and MCPM, respectively.

Table 1 shows the $\mathrm{pH}$ of the reaction medium after hydrothermal treatment of DCPD and MCPM at various $\mathrm{NaHCO}_{3}$ concentrations. The $\mathrm{pH}$ increased with increasing $\mathrm{NaHCO}_{3}$ concentration. It remained below 5 for reaction media resulting from DCPD and MCPM treated at or below 0.1 and $0.5 \mathrm{~mol} / \mathrm{L}$ $\mathrm{NaHCO}_{3}$, respectively. Media from treated DCPD crystals displayed higher $\mathrm{pH}$ values than from treated MCPM crystals for all $\mathrm{NaHCO}_{3}$ concentrations.

Figures 4(a) and 4(b) show the FT-IR spectra of treated DCPD and MCPM crystals, respectively. The hydrothermal treatment of DCPD and MCPM in the presence of 0.5 and $1 \mathrm{~mol} / \mathrm{L} \mathrm{NaHCO}_{3}$, respectively, gave rise to similar spectra. Specifically, typical $\mathrm{PO}_{4}$ vibration bands of HAp were detected at $1021 \mathrm{~cm}^{-1}$ along with 


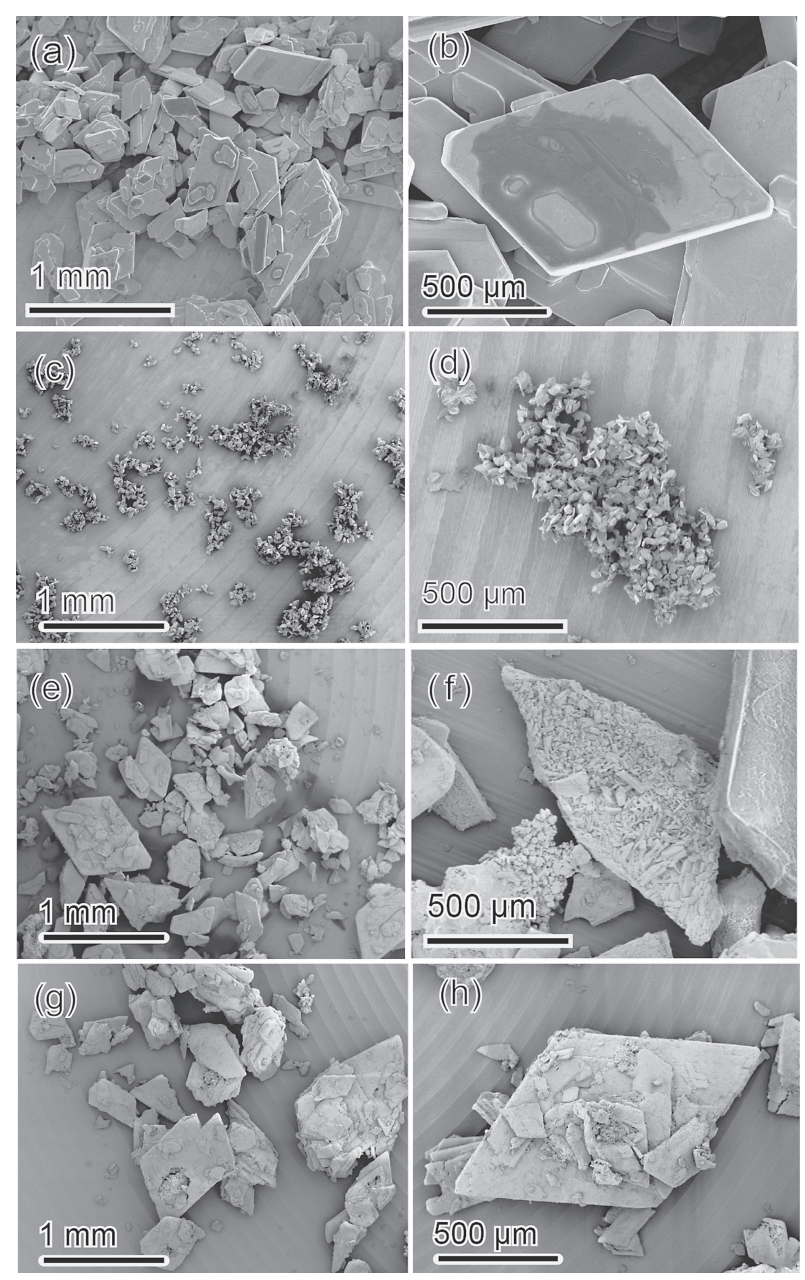

Fig. 2. SEM micrographs of MCPM (a, b) before and (c, d) after hydrothermal treatment with 0.1 , (e, f) 1 , and $(\mathrm{g}, \mathrm{h}) 5 \mathrm{~mol} / \mathrm{L} \mathrm{NaHCO}_{3}$.
$\mathrm{CO}_{3}$ stretching bands at 1420 and $1460 \mathrm{~cm}^{-1}$, indicating the formation of B-type apatite by the substitution of $\mathrm{PO}_{4}{ }^{3-}$ in $\mathrm{HAp}$ by $\mathrm{CO}_{3}{ }^{2-}$. However, low intensity $\mathrm{CO}_{3}$ stretching bands were observed at 1525 and $1540 \mathrm{~cm}^{-1}$, consistent with the replacement of $\mathrm{OH}^{-}$by $\mathrm{CO}_{3}{ }^{2-}$ in $\mathrm{HAp}$ to give A-type apatite. ${ }^{20)}$ Furthermore, a band was observed at $866 \mathrm{~cm}^{-1}$ for DCPD and MCPM treated above 1 and $5 \mathrm{~mol} / \mathrm{L} \mathrm{NaHCO}_{3}$, indicating that $\mathrm{CO}_{3}{ }^{2-}$ adsorbed onto the apatitic structure. ${ }^{21), 22)}$ Consequently, DCPD and MCPM crystals were completely converted into $\mathrm{CO}_{3} \mathrm{Ap}$ while retaining their initial morphologies when treated with $\mathrm{NaHCO}_{3}$ solutions at and above 0.5 and $1 \mathrm{~mol} / \mathrm{L}$, respectively.

The $\mathrm{CO}_{3}$ incorporation into the apatitic unite lattice was estimated using XRD peak shifts. Figure 5 plots the $a$ - and $c$-axes lattice parameters of apatite as a function of the $\mathrm{NaHCO}_{3}$ concentration. The lattice parameters of apatite were taken from calibrated XRD patterns by $\alpha$-alumina peak positions (Figure S1). The $c$-axis lattice parameter did not show any significant changes, irrespective of the $\mathrm{NaHCO}_{3}$ solution concentration. In contrast, the $a$-axis lattice parameter decreased on increasing the $\mathrm{NaHCO}_{3}$ solution concentration.

The $\mathrm{CO}_{3}$ content was evaluated by $\mathrm{CHN}$ analysis. Figure 6 shows the $\mathrm{CO}_{3}$ content as a function of $\mathrm{NaHCO}_{3}$ concentration. Treated DCPD crystals presented higher $\mathrm{CO}_{3}$ content than MCPM crystals regardless of $\mathrm{NaHCO}_{3}$ concentration. The $\mathrm{CO}_{3}$ content of DCPD and MCPM crystals treated with $5 \mathrm{~mol} / \mathrm{L}$ $\mathrm{NaHCO}_{3}$ amounted to 10.5 and 7.1 mass \%, respectively.

Figure 7 shows TEM images of treated DCPD $(a, b)$ and MCPM (c, d). The treated DCPD fine structure mainly consisted

Table 1. $\mathrm{pH}$ values of distilled water after treatment with DCPD or MCPM in various concentration of $\mathrm{NaHCO}_{3}$ at $200^{\circ} \mathrm{C}$ for $24 \mathrm{~h}$

\begin{tabular}{ccc}
\hline $\mathrm{NaHCO}_{3}$ concentration $(\mathrm{mol} / \mathrm{L})$ & DCPD & MCPM \\
\hline 0 & 4.28 & 1.75 \\
0.1 & 4.41 & 1.91 \\
0.5 & 6.62 & 2.57 \\
1 & 7.05 & 5.20 \\
5 & 9.72 & 9.59 \\
\hline
\end{tabular}

\section{DCPD}

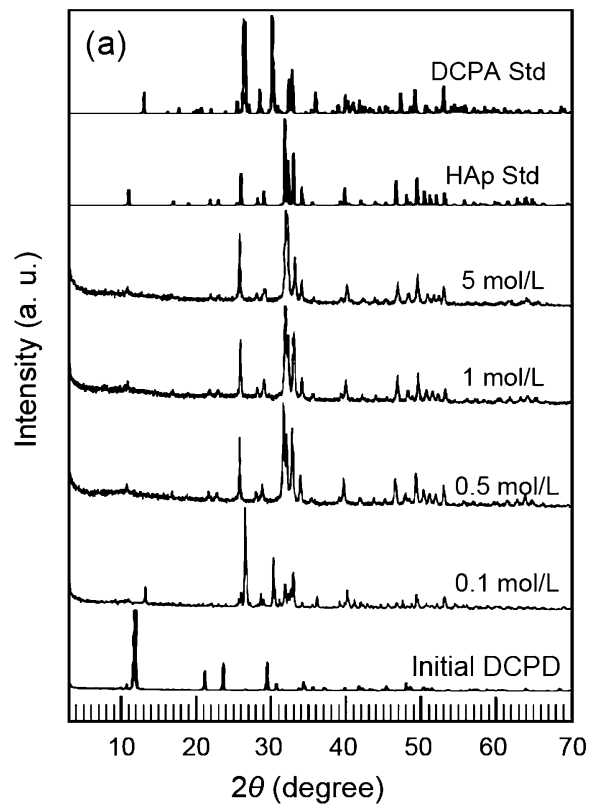

MCPM

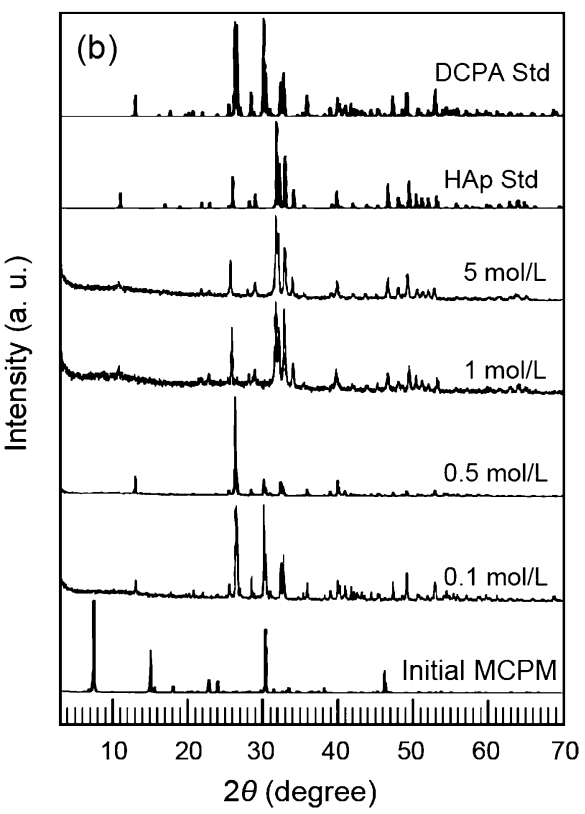

Fig. 3. XRD patterns of (a) DCPD and (b) MCPM after hydrothermal treatment at various $\mathrm{NaHCO}_{3}$ concentrations. 

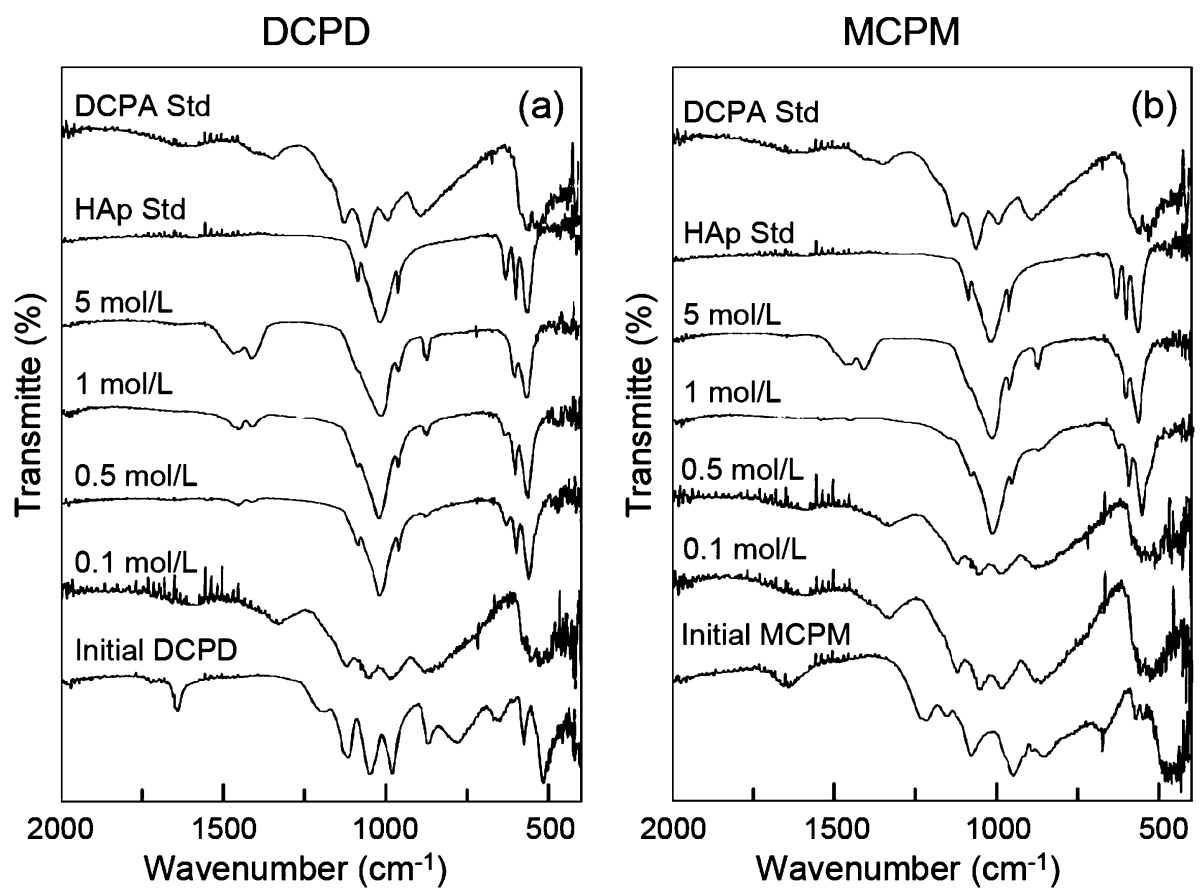

Fig. 4. FT-IR bands of (a) DCPD and (b) MCPM after hydrothermal treatment at various $\mathrm{NaHCO}_{3}$ concentrations.
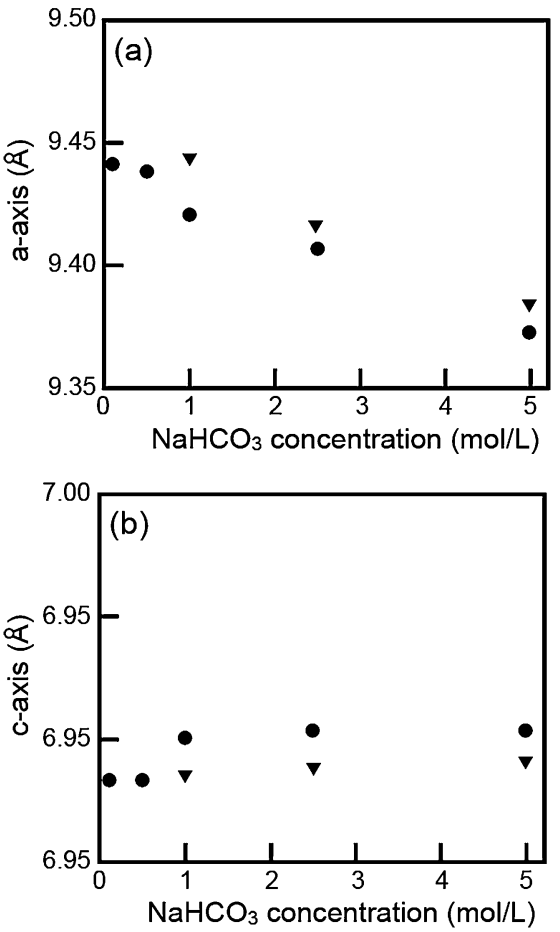

Fig. 5. Lattice constants calculated from observed (002) and (300) peaks as a function of $\mathrm{NaHCO}_{3}$ concentration. Closed circles and closed triangles correspond to DCPD and MCPM, respectively. (a) $a$-axis; (b) $c$-axis. $1 \AA=0.1 \mathrm{~nm}$.

of hexagonal plate-like crystals approximating $20 \mathrm{~nm}$. These crystals generated so-called mesocrystal structures through a complex assembly process. ${ }^{23)-26)}$ High resolution TEM (HRTEM) observations showed unidirectional lattice fringes, suggesting that $\mathrm{CO}_{3} \mathrm{Ap}$ formed in the individual plate-like crystals. Treated MCPM displayed essentially the same as fine structure and components as its DCPD counterpart.

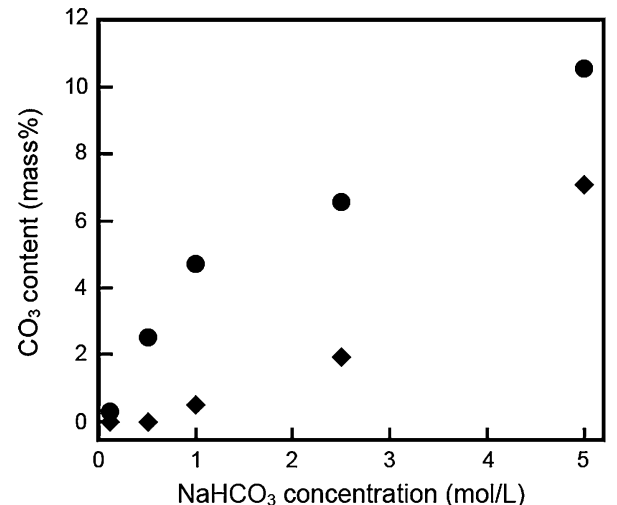

Fig. 6. $\mathrm{CO}_{3}$ content after hydrothermal treatment as a function of $\mathrm{NaHCO}_{3}$ concentration. Closed circles and closed triangles correspond to DCPD and MCPM, respectively.

\section{Discussion}

Hydrothermal treatment of DCPD and MCPM crystals at $200^{\circ} \mathrm{C}$ and above 0.5 and $1 \mathrm{~mol} / \mathrm{L} \mathrm{NaHCO}_{3}$, respectively, lead to their complete conversion into $\mathrm{CO}_{3} \mathrm{Ap}$ after $24 \mathrm{~h}$. In addition, this treatment did not alter the macroscopic morphology of the crystals.

However, $\mathrm{CO}_{3} \mathrm{Ap}$ formation was limited to basic conditions in the presence of sufficient $\mathrm{CO}_{3}{ }^{2-}$.2),3) The dissolution of DCPD and MCPM freed $\mathrm{H}^{+}$as described by

DCPD: $\mathrm{CaHPO}_{4} \cdot 2 \mathrm{H}_{2} \mathrm{O} \rightarrow \mathrm{Ca}^{2+}+\mathrm{PO}_{4}{ }^{3-}+\mathrm{H}^{+}+2 \mathrm{H}_{2} \mathrm{O}$

MCPM: $\mathrm{Ca}\left(\mathrm{H}_{2} \mathrm{PO}_{4}\right)_{2} \cdot \mathrm{H}_{2} \mathrm{O} \rightarrow \mathrm{Ca}^{2+}+2 \mathrm{PO}_{4}{ }^{3-}+4 \mathrm{H}^{+}+\mathrm{H}_{2} \mathrm{O}$

Therefore, $\mathrm{NaHCO}_{3}$ acted as a $\mathrm{CO}_{3}{ }^{2-}$ source and a $\mathrm{pH}$ buffer under weakly basic conditions:

$$
\mathrm{HCO}_{3}{ }^{-}+\mathrm{H}^{+} \rightleftarrows \mathrm{H}_{2} \mathrm{CO}_{3}
$$




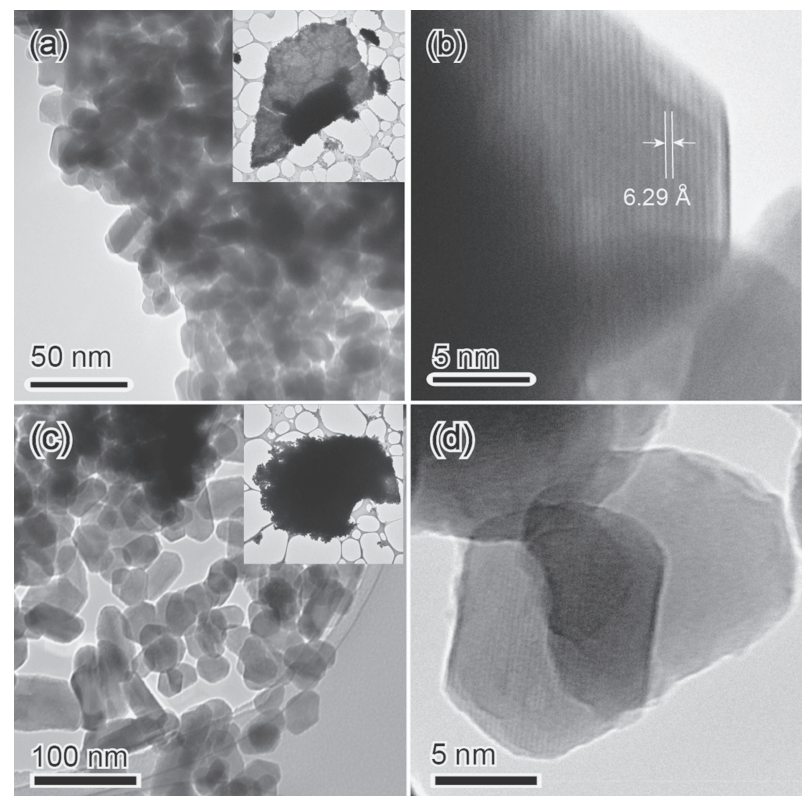

Fig. 7. (a, c) TEM micrographs of treated crystals showing a mesoscale structure and $(b, d)$ high-resolution TEM micrographs of single hexagonal plate-like crystals presenting a mesoscale structure. (a, b) DCPD treated with $5 \mathrm{~mol} / \mathrm{L} \mathrm{NaHCO}_{3}$. (c, d) $\mathrm{MCPM}$ treated with $5 \mathrm{~mol} / \mathrm{L}^{\mathrm{NaHCO}}$. Insets: corresponding low-magnification TEM micrographs.

The released $\mathrm{H}^{+}$was absorbed and the $\mathrm{pH}$ was titrated by $\mathrm{NaHCO}_{3}$ buffering. However, below 0.5 and $1 \mathrm{~mol} / \mathrm{L} \mathrm{NaHCO}_{3}$ for DCPD and MCPM, respectively, the released $\mathrm{H}^{+}$yielded to $\mathrm{NaHCO}_{3}$ buffering, causing the $\mathrm{pH}$ to decrease. Consequently, only acidic calcium phosphate materials, such as DCPA and octacalcium phosphate (OCP), were formed without apatitic phases. The MCPM-derived $\mathrm{H}^{+}$displayed a greater activity than its DCPD equivalent because of the higher $\mathrm{H}^{+}$ratio in MCPM than in DCPD. Therefore, the MCPM system required higher amounts of $\mathrm{NaHCO}_{3}$ than its DCPD analogue for $\mathrm{pH}$ titration.

This study assumed that the ribbon-like OCP formed under acidic conditions was converted into HAp while maintaining its morphology. Several previous works indicates that OCP readily transformed into HAp with a pseudomorphic relationship in a hydrothermal environment. ${ }^{2), 27)-30 \text { ) }}$

The $\mathrm{pH}$ of the solution was titrated by $\mathrm{NaHCO}_{3}$ buffering under weakly basic conditions. The dissolution of DCPD and MCPM produced $\mathrm{Ca}^{2+}$ and $\mathrm{PO}_{4}{ }^{3-}$, which built up to concentrations exceeding the solubility of $\mathrm{CO}_{3} \mathrm{Ap}$. Under weakly basic conditions, $\mathrm{CO}_{3} \mathrm{Ap}$ was in a stable phase, which promoted its formation [Eq. (1)].

According to the heterogeneous nucleation theory, $\mathrm{CO}_{3} \mathrm{Ap}$ crystal seeds randomly formed on DCPD and MCPM surfaces. ${ }^{31)}$ Therefore, the resulting crystals covered the precursors, maintaining their original morphologies. These $\mathrm{CO}_{3} \mathrm{Ap}$ crystals began to grow when DCPD and MCPM crystals dissolved, gradually replacing the precursors.

Large amounts of $\mathrm{CO}_{3}{ }^{2-}$ inhibited $\mathrm{CO}_{3} \mathrm{Ap}$ formation. FT-IR spectra and peak shift estimates showed that $\mathrm{CO}_{3}{ }^{2-}$ was incorporated into the apatitic unit lattice and adsorbed onto $\mathrm{CO}_{3} \mathrm{Ap}$ crystallites. In addition to the $\mathrm{CO}_{3}$ stretching bands detected at 1420 and $1460 \mathrm{~cm}^{-1}$ for $\mathrm{CO}_{3} \mathrm{Ap}$, the band at $866 \mathrm{~cm}^{-1}$ was consistent attributable to $\mathrm{CO}_{3}{ }^{2-}$ adsorbed onto the apatitic structure, ${ }^{21), 22)}$ which inhibited $\mathrm{CO}_{3} \mathrm{Ap}$ growth. ${ }^{10), 21), 22)}$ As a result, the growth process generated a plethora of small $\mathrm{CO}_{3} \mathrm{Ap}$ crystals. This phenomenon may be utilized to maintain fine structures by analogy to the number of pixels, which greatly improves the resolution of a picture when increasing.

\section{Conclusion}

In this study, $\mathrm{CO}_{3} \mathrm{Ap}$ was obtained by hydrothermal treatment of DCPD and MCPM in the presence of $\mathrm{NaHCO}_{3}$. The product retained the morphologies of the precursors. In addition to an easy crystallization, these acidic calcium phosphate salts benefit from greater water solubility than other $\mathrm{CO}_{3} \mathrm{Ap}$ precursors, which strongly affects the phase conversion ratio. Therefore, the newly developed $\mathrm{CO}_{3} \mathrm{Ap}$ synthesis may lead to rapid fabrication methods for shape-controlled $\mathrm{CO}_{3} \mathrm{Ap}$ compacts.

Acknowledgement This study was financially supported in part by the Strategic Promotion of Innovative Research and Development Program, Japan Agency for Medical Research and Development, a Grant-in-Aid for Research Activity Start-up by the Japan Society for the Promotion of Science (JSPS) grant number (15H06488), and Kyushu University Interdisciplinary Programs in Education and Projects in Research Development (P\&P), Kyushu University, Japan.

\section{References}

1) K. Ishikawa, Mater., 3, 1138-1155 (2010).

2) L. Wang and G. H. Nancollas, Chem. Rev., 108, 4628-4669 (2008).

3) J. C. Elliott, "Studies in Inorganic Chemistry 18, Structure and Chemistry of the Apatites and Other Calcium Orthophosphates", Elsevier Co., the Netherland (1994).

4) B. D. Ratner, A. S. Hoffman, F. J. Schoen and J. E. Lemons, "Biomaterial Science: An Introduction to Materials in Medicine", 3rd ed., Academic Press, Elsevier Co., the Netherland (2013)

5) Y. Sugiura, K. Onuma, Y. Kimura, H. Miura and K. Tsukamoto, J. Cryst. Growth, 332, 58-67 (2011).

6) R. M. Wilson, S. E. P. Dowker and J. C. Elliott, Biomater, 27 , 4682-4692 (2006).

7) R. Z. LeGeros, Nature, 206, 403-404 (1965).

8) S. Raynaud, E. Champion, D. Bemache-Assollant and P. Thomas, Biomater., 23, 1065-1072 (2002).

9) A. A. Baig, J. I. Fox, R. A. Young, Z. Wang, J. Hsu, W. L. Higuchi, A. Chhettry, H. Zhuang and M. Otsuka, Calcif. Tissue Int., 64, 437-449 (1999).

10) Y. Sugiura, K. Tsuru and K. Ishikawa, Ceram. Int., 42, 204210 (2016).

11) H. Wakae, A. Takeuchi, K. Udoh, S. Matsuya, M. Munar, R. Z. LeGeros, A. Nakashima and K. Ishikawa, J. Biomed. Mater. Res., Part A, 87, 957-963 (2008).

12) K. Sunouchi, K. Tsuru, M. Maruta, G. Kawachi, S. Matsuya, Y. Terada and K. Ishikawa, Dent. Mater. J., 31, 549-557 (2012).

13) S. Nomura, K. Tsuru, M. Maruta, S. Matsuya, I. Takahashi and K. Ishikawa, Dent. Mater. J., 33, 166-172 (2014).

14) F. Daitou, M. Maruta, G. Kawachi, K. Tsuru, S. Matsuya, Y. Terada and K. Ishikawa, Dent. Mater. J., 29, 303-308 (2010).

15) A. Takeuchi, M. L. Munar, H. Wakae, M. Maruta, S. Matsuya, K. Tsuru and K. Ishikawa, Biomed. Mater. Eng., 19, 205-211 (2009).

16) C. T. Zaman, A. Takeuchi, S. Matsuya, Q. H. M. S. Zaman and K. Ishikawa, Dent. Mater. J., 27, 710-715 (2008).

17) N. X. T. Tram, M. Maruta, K. Tsuru, S. Matsuya and K. Ishikawa, Adv. Biocera. Porous Cera., 4, 59-65 (2014).

18) Y. Lee, Y. M. Hahm, S. Matsuya, M. Nakagawa and K. Ishikawa, J. Mater. Sci., 42, 7843-7849 (2007).

19) N. Koga, K. Ishikawa, K. Tsuru and I. Takahashi, Ceram. Int., in press.

20) R. Z. LeGeros, O. R. Trautz, E. Klein and J. P. LeGeros, Exp. $A, 25,14-16$ (1969).

21) A. Kaflak, A. Slosarczyk and W. Kolodziejski, J. Mol. Struct., 
997, 7-14 (2011).

22) C. Rey, C. Combes, C. Drouet and M. J. Glimcher, Osteoporos. Int., 20, 1013-1021 (2009).

23) H. Imai, J. Ceram. Soc. Japan, 122, 737-747 (2014)

24) Y. Nakagawa, H. Kageyama, Y. Oaki and H. Imai, J. Am. Chem. Soc., 136, 3716-3719 (2014).

25) F. C. Meldrum and H. Colfen, Chem. Rev., 108, 4332-4432 (2008).

26) H. Colfen and M. Antonietti, "Mesocrystals and Nonclassical Crystallization", Wiley \& Sons Ltd, USA (2008).
27) W. E. Brown, L. W. Schroeder and J. S. Ferris, J. Phys. Chem., 83, 1385-1388 (1979).

28) M. Kamitakahara, N. Ito, S. Murakami, N. Watanabe and K. Ioku, J. Ceram. Soc. Japan, 117, 385-387 (2009).

29) D. G. A. Nelson and G. H. McLean, Calcif. Tissue Int., 36, 219-232 (1984).

30) Y.-H. Tseng, C.-Y. Mou and J. C. C. Chan, J. Am. Chem. Soc., 128, 6909-6918 (2006).

31) I. Sunagawa, "Crystals Growth, Morphology and Perfection", Cambridge University Press, UK. (2005). 